\title{
HOW TO TELL - AND UNDERSTAND - A DIRTY JOKE IN KILIVILA
}

\author{
Gunter SENFT*
}

Jokes made by 'rather exotic' speech communities are hardly to be found in the literature on aspects of humor. This paper presents and analyzes a joke told by a Trobriand islander in the Kilivila language. The analysis emphasizes the fact that to understand the contents, the humor of a joke, and the way the joke is told depends on one's knowledge of the pragmatic conventions of the speech community in which this joke is told. Moreover it is shown that jokes within the Kilivila speech community are just one class of speech acts that constitute a special 'situational-intentional' language variety which is called biga sopa. This Kilivila concept of sopa is defined and its social function is explained.

\section{Introduction}

Humorous joking seems to be one of the universal traits in human communication. Although the number of monographs and anthologies on humor in general and on jokes in particular is incredibly high, one hardly finds examples of jokes or humorous stories told by peoples of non-European origin, peoples that can be labeled - by European standards - as 'rather exotic'. One of the reasons for this fact may be that these 'rather exotic' peoples tell their jokes in their 'rather exotic' languages, referring to incidents in their 'rather exotic' setup. Thus to present those peoples' jokes asks for an understanding of both their language and their cultural background. A commonly used strategy in humor is (as Dolitsky (1983: 47) has put it) to go "against the pragmatic conventions of a linguistic community, i.e. stating the normally unsaid, or

* This study is based on the results of 15 months of field research in Tauwema village on Kaileuna Island, one of the Trobriand Islands in Papua New Guinea. I want to thank the 'Deutsche Forschungsgemeinschaft' for financing our project; I am also very much indebted to the applicants for the project 'Ritual Communication on the Trobriand Islands', I. Eibl-Eibesfeldt, V. Heeschen, and W. Schiefenhövel - and the 'Forschungsstelle für Humanethologie am Max-PlanckInstitut für Verhaltensphysiologie' for their support in this project. I would like to thank Wolfgang Klein, Hartmut Haberland, and my wife for their critical remarks on the first version of this paper. I owe Ed Wilmsen thanks for having corrected what the author supposed to be English. Last but not least I want to thank my informants on the Trobriand Islands for their hospitality, friendliness, and patient cooperation.

Author's address: G. Senft, Forschungsstelle für Humanethologie am Max-Planck-Institut für Verhaltensphysiologie, 8131 Seewiesen, FRG. 
omitting the normally said". Understanding humor presupposes in this case knowledge of these conventions; very often they consist in "cultural constraints on certain conversational subjects" like "sex, excretion and money" (Dolitsky (1983: 40)).

This paper presents, and attempts to analyze, a joke which (like all jokes) is "built in the form of a story" " (Sacks (1974: 337)), a joke told within such a 'rather exotic' speech community. The joke - which can be labeled as 'dirty' (in accordance with Sacks $(1974,1978)$ ) because of its 'obscene' components - was told to me by Chief Kilagola in Tauwema village on Kaileuna Island. Kaileuna is one of the Trobriand Islands, situated in the Milne Bay Province of Papua New Guinea, in the middle of the Solomon Sea. The islands became famous in anthropological circles especially because of Bronislaw Malinowski's masterpieces on Trobriand culture. The language of these islanders is called Kilivila; it is an Austronesian (VOS-)language which belongs to the "Papuan-TipCluster" group (Capell (1976: 6,9), Senft (1984)).

The analysis of the joke is based on the results of a 15 months' field research in the Trobriands in 1982-1983. In the following sections I will first present the data and the way they were collected; next I will try to explain how this particular joke is to be understood; then I attempt to analyze how this 'dirty' joke is told; finally I essay to integrate this joke into the overall Kilivila concept of biga sopa as one feature of this so linguistically and culturally prominent concept. But let us first have a look at the data.

\section{The joke}

At about 9 p.m., three hours after sunset, on the 9th of May 1983, Kilagola, the approximately 62 year-old chief of Tauwema village, came to our house together with his wife Sibwesa to join our little group there, consisting of my wife Barbara, my friend and informant Weyei, one of Kilagola's brothers, and me. Both Kilagola and Weyei were chewing betel-nut, and the atmosphere was

1 I have hesitated between calling this piece a 'joke' and a 'funny story' (as Wolfgang Klein and Hartmut Haberland suggested discussing this topic). I decided on the label 'joke', however, because of the following considerations: The story is clearly marked as 'fictional'. A joke is always fictional, but this need not be so for a 'funny story'. The story starts off with two incompletive verb forms in line 24: bisisusi bilosi, and the incompletive appears frequently throughout the story (like in bilosi line 27, bikau line 28), along with verb forms in other moods and aspects (neutral ekalibomsi line 26 and iputupuma line 31). Starting a story with a verbal expression in the incompletive is the grammatical means to express the fictitious character of a joke, which is told in the form of a story, of course. All the 21 stories I collected besides this joke use the neutral form of the verbal expression with which they start. Moreover, stories - funny stories included - are usually longer, showing much more epic verbosity than the joke presented. The most important argument for my decision, however, is the fact that the Trobriand Islanders characterize this story ( $k u k w a n e b u)$ as sopa - which can also mean joke; they do not use this label for the other stories I collected, including fairy tales for children (see also the last section of the paper). 
friendly, relaxed, and sympathetic as was usual; we were talking and gossiping about the day's events and trivialities.

The day before, Kilagola had made a present to Barbara and me: he had given us one of his artistically carved sticks of ebony that showed amongst other things two men. While carving it, the chief, who is well known on the Trobriands as one of the mastercarvers, had told me that there is a story with these two men as its protagonists. During the evening, Kilagola looked quite often at this artefact; thus I thought it a good opportunity to ask him about the story he had hinted at before. He agreed quite freely and happily and he had no objections at all against my wish to record the story on tape.

The following data represent the transcription of my eliciting the story and Kilagola's reaction to it. The left side of my transcription represents the actual 'interview' in Kilivila; the orthography of Kilivila presented here is preliminary, it is oriented towards the - as yet unexplicated - system of Lawton's translation of the Four Gospels (1979). On the right side of the transcription, I give the English translation of this interview in an attempt to be as literal as possible.

Gunter:

Kilagola yokwa kulivala pela beya tokwalu kukwanebu esisu

Kilagola:

e kugisila a ke kumeya (laughter)

kumeya ba'yosi balivala

Gunter:

5 e bwena

Kilagola:

sogu mpana kukwanebu $+\mathrm{ka}+++$

mpana kukwanebu +++

gala bavagi tetolula

tetolula bavagi

10 inasi inasi

e mtona yagala Mulagugula

e mtona yagala Mulakwaku

e mtona Mulakwaku tomanabweta

taga mtona Mulagugula tomigaga

15 taga beya lavagi ebwena

taga kabulula beya bitoki
Kilagola, you - you said with this (piece of) carving there is a story.

Yes, you see, indeed, ah - well - bring it,

(laughter) bring it, I will hold it, I will tell (the story).

Yes, good.

My friend, this story (pause), well ... (pause)

this story ... (pause) ......

I could not make three persons -

three persons I should carve -

their mother - their mother.

Well, this man here - his name is Mulagugula,

and this man there - his name is Mulakwaku.

And this Mulakwaku is a beautiful man,

but this Mulagugula is an ugly man. Anyhow, here I did it, it is good.

Indeed, his nose here, it may be called prominent, 
matala bima beya +++

matala bima beya

e inasi gala bavagi pela kai kekukupi

20 adoki basela inasi beya

e mtona Mulagugula beya

e mtona bwadala

Mulakwakula mtona +++

bisisusi bilosi

25 ekalibomsi Omarakana

bilosi ekalibomsi

bwadala bilosi ekakayasi

bilosi bimesi

bikau nuya ekukwali

30 ekukwali bivokwa

iputuputuma makala pauda

e hima isimwa

e mtonaga biloki popu (laughter)

biloki popu (laughter) bigaki la putuma

35 epu ... (laughter) ... eputuputuma

bivokwa

bilosi Omarakana

bivesi "he maina popu" (laughter)

elagi evavagigo

bitoka "eseki

40 puvami tolivalu yakamesi ugwavaga"

e eta'inaga evava'isi kesosau

bitita'inaga ekalibomsi

"he maina popu tauvau"

"eseki pwami tolivalu" (laughter)

$++$

45 bita'ina bita'ina bikalibom bogwala

"he maina popu"

"tauvau kuvagisi his eye, it will come here (he is crosseyed) ...... (pause) ......

his eye, it will come here.

And their mother I could not carve, because the stick was too small.

I think I should put their mother here, and this Mulagugula here,

and this one, his brother,

Mulakwakula, this one here $\ldots \ldots$ (pause) ......

They might have lived, they would go they do the 'kalibom' (they drum and sing or walk around the singers and drummers) at Omarakana village.

They would go, they do the 'kalibom'.

His brother - they would go, they bathe,

they would go, they would come -

he would fetch a coconut, he scrapes it, he scrapes it, he will finish it, he oils (his body) - like powder yes, he will come, he stays (there).

Yes, and this one there, he will go for shit (laughter),

he will go for shit (laughter) he will make it his oil.

He oi ... (laughter) ... he 'oils' (his

body), he will finish it.

They will go to Omarakana.

They will be on their way. "Hey! The smell of shit!" (laughter)

He hears it, he who has done this.

$\mathrm{He}$ will stand there (and say): "Maybe it is

your shit, villagers - we are strangers".

Yes, he walks around again, they hit the big drum

he will walk around and around, they do the 'kalibom'.

"Hey! The smell of shit, men!"

"Maybe it is your shit, villagers". (laughter - pause)

$\mathrm{He}$ will walk around, he will walk around, he will do the 'kalibom' again already -

"Hey! The smell of shit!"

"Men, you did it! 
avela pwala

eseki maina pwami

50 kweyasi mikukwava komasi ami popu ayobali ayobilibaliga

sulubebeva kwanadugumasi"

mtona Mulakwa... Mulagugula la biga makala

eta'ina bima bimesi sola bwadala

$+++$

55 bimeki minana bunukwa

bikamkwam o kala kevaga

o kala kaboma

"yai yai kamwala koma am popu"

esakaula bunukwa

60 itoliga ikam bikamkwam

bivokwa ekabi

bima o sivalu sola inala

bwadalaga ivakola vivila

oluvi ilola

65 yam yam lepaisewa

makala mtona Mulagugula

e mtonaga Mulakwakula mtona tomanabweta

vivila bivakola e ivai mtona

mtonaga gala vevai sena tomigaga

70 e kugisi lateya beya

taga u'ula kai kekukupi

bascla inasi inasi

vivila basela beya

Mulagugula Mulakwakula +++

Gunter:

75 e avaka beya

Kilagola:

beya $++t$ beya adoki makala vatunu vatunu adoki

bavagi vatunu yabwabava

taga avagi gala
Whose arse (is it)?

Maybe it is the smell of your arses -

fuck your wives, eat your shit.

I stay (here), I stay here, indeed -

(there will be much) tumbling down, if you (try to) rush at me to fight me".

This Mulakwa... Mulagugula's speech (was) so.

He walks around, he will come - they

will come - (he) together with his

brother (pause)

he will come to this pig,

he will eat it on his wooden plate,

on his plate.

"Oh no! Your only food (will be): eat. your shit!"

(And with this said) it runs away, the pig.

He stands there, he eats, he will eat, he will finish it, he walks off.

He will come to their village together with his mother.

His brother, indeed, he is holding hands with a girl, bringing her to his house.

Then he goes away.

Day by day he did his work.

Like this was this Mulagugula

And this one, Mulakwakula, he was beautiful.

He may hold hands with a girl, bringing her to his house, and he marries (her), this one.

But this one does not marry (a girl - he is) so ugly.

Well, you see, I carved it here, however, because the stick is so small, I will put their mother, their mother and the girl I will put here, and Mulagugula and Mulakwakula (pausc).

And what is this?

This ... (pause) ... this, I think, is like a string, a string, I think.

I could carve strings, plenty of them, but I did not do it. 
kekekita kai e bogwa mesinau

80 beya evagi ibubuli kunula beya

kidamwa lakabogigisa mwata makala mwata

e beyaga vatunu makala esekwani yata

miyana ele'i ema beya

ema ikikola beya vatunu miyana

85 yatala yayu miyasita vatunu

Gunter:

bwena agutoki (laughter)

Kilagola:

bateya ketala bavagi migila Mulagugula

bibwena tomigaga

e kabulula beya matalaga himwa

90 itomwa beya (laughter)

inasi bavagi vivila inasi

bavagi inasi

e bukugisi ++

Gunter:

sena bwena
The small stick - and it is finished already.

This makes, this is carved at its top, here,

as if a snake appeared - like a snake;

and here a string, like one being rolled up -

this one is thrown and comes this way here,

it comes, it stops here, this string -

one, two of these strings there.

Good, thank you (laughter).

I will carve another one, I will do Mulagugula's face (again),

it will be good - such an ugly man,

and his nose here, his eye, it will come (like this),

he will stand here (laughter),

their mother, I will carve the girl, their mother,

I will carve their mother.

Yes, you will see (pause).

Very good.

This interview lasted 2.5 minutes only. Now, with these data given we may ask: What should be so funny with the story Kilagola tells here? How do we have to understand all this? The following sections try to answer these questions.

\section{How to understand the joke}

If we look at the interview as a whole, we realize at first sight that Kilagola starts and ends his telling the joke, the story that goes with the wooden stick he had carved, by critical comments on his carving, by explaining all the bits and pieces of the carving, and by stating that he plans to do it again in a more refined way in order to come even closer to the story he wanted to express with his artefact. I will analyze these parts of the interview (lines 1-23 and lines 7094) in the next section in detail; for our purpose here 1 may just note that Kilagola introduces the two protagonists of the story, Mulagugula and Mulakwaku, in lines 10 and 11, describes them in lines 12-14 and 16-18 Mulakwaku as a beautiful, a handsome man, and Mulagugula as ugly, cross- 
eyed, and with a very prominent nose - and states in line 22 that the two men are brothers. The actual story, the joke, however, starts with line 24 and ends with line 69 . It is these 46 lines of the transcript that this section deals with.

The joke proper starts with the information that the two brothers want to go to the village of Omarakana to attend the kalibom (lines 24-26). Here the naive, non-Trobriand reader or listener should be aware of the following two facts: Omarakana is something like the 'capital' of the Trobriand Islands: it is the paramount chief's village, the village of the chief who is regarded as the most important, influential, and politically most powerful chief of the Trobriand Islands. The kalibom is a kind of festivity, mostly performed during the nights of the 'harvest festival' or milamala-period, where a group of drummers and singers meet in the middle of the village and sing the so-called milamala songs that are sung in a rather archaic variety of Kilivila and describe very poetically and erotically the life of the spirits of the dead, the baloma in the villages of Trobriand 'paradise' in Tuma Island (Malinowski (1916)). While some of the villagers, mostly men, do the drumming and singing, other villagers and guests - both male and female - walk around this group, chatting and flirting a lot. It is only here that men and women, especially male and female bachelors, have the opportunity not only to flirt very openly and in a relatively direct manner, but also to have first bodily contacts like holding hands or walking very closely side by side. This is quite often a good opportunity to arrange dates, for guests as well as for the villagers that do the kalibom. Thus going to attend a kalibom - especially if it is performed in another village - almost always implies an amorous component for a Trobriand Islander (cf. Malinowksi (1929: $211 \mathrm{ff}$.)).

Now with this in mind, it is only logical for a young man on the Trobriand Islands to prepare himself very carefully for this event - he will go and have a bath and then oil his body with coconut flakes in order both to smell and look good. This is exactly what the story tells us about the two brothers in lines 2732. However, Mulagugula does not use coconut oil on his body after the bath, as his brother does he, the ugly one, takes shit instead and 'oils' his body with excrement - thus revealing that he is not only ugly but also crazy: the Trobrianders are very sensitive to bodily odors and dirt (Malinowski (1929: $255,375 \mathrm{ff}$.$) ). With these preparations finished Mulakwaku and Mulagugula$ are on their way to Omarakana (lines 33-36).

When the brothers arrive in Omarakana, the people there immediately smell Mulagugula's terrible odor and react with the same kind of scolding (line 37) they direct toward careless children coming back from the toilet, or toward some villages with very poor sanitary conditions (Malinowski (1929: $375 \mathrm{ff}$.).

We have to emphasize here that this obviously public scolding is done by the villagers of Omarakana. As we remember, Omarakana is the village of the paramount chief: in Trobriand eliquelle surrounding a chief, it is officially and naturally acknowledged that such rather drastic expressions are avoided and 
replaced by certain euphemisms. Nevertheless, the tabooed expression is used here; this may indicate that either Mulagugula's smell was so shocking that even the Omarakana people forgot their etiquette or that the inhabitants of the paramount chief's village just do not know what kind of good manners they owe to their own chief - or even that the official code of etiquette is exposed as being vacuous. These implications thus reveal a rather gross way of joking in combination with highly political and sarcastic satire.

The story now continues to work on this topic of breaking a taboo (lines 38 40): Mulagugula hears the villagers' scolding when he arrives at Omarakana. He boldly stands there and accuses the people of Omarakana of being responsible for the bad odor in their village; moreover, by emphasizing the fact that he and his brother are strangers, he implies in a very subtle figure of speech that they - as strangers - are not used to such odors as one smells here in Omarakana. Here the subtlety of Mulagugula's second sentence sharply contrasts with his very crude and taboo-breaking first sentence, which is directed to all villagers of Omarakana, including the chief; a gross and deadly insult of the paramount chief which normally asks for bloody revenge (Malinowski (1929: 377)). Although this must be evident even for Mulagugula, he joins the people doing the kalibom, walking around the group that beats the big drums and sings the songs - just as if nothing important had happened at all (lines $41-42$ ).

The other people attending the kalibom obviously cannot stand Mulagugula's terrible smell and they complain about the odors a second time. Mulagugula again accuses the villagers of Omarakana of being responsible for this condition and continues walking around at the kalibom festivity (lines 43-45).

But the Omarakana people complain a third time about the smell of excrement (line 46). One may wonder here, why the Omarakana villagers do not directly charge the man who is obviously responsible for the bad odor in their village. This can either be explained by a necessity, immanent in the story, to make the joke work - or as another aspect of critical satire at the cost of the Omarakana people, implying that they are so conceited and pretend to be so distinguished and refined that they do not realize the obvious at first sight if it is this far away from their pretended standards, or that they hesitate to call a spade a spade.

Mulagugula reacts to this third hint towards bad odors by just such a blunt and open accusation together with a rhetorical question, drastically calling the place of origin of this odor by name; then he accuses the villagers that this odor of excrement stems from their asses; with this he implies that the villagers are like children that have not learned yet how to clean themselves before coming back from the bush. Now Mulagugula's insults escalate and he produces the two worst and most taboo-breaking curses of the Trobrianders: 
- kweyasi mikukwava 'fuck your wives' is, according to Weiner (1976: 195f.) "the most horrendous insult, with dire consequences, ... to say to a man" (see also Weiner (1976: 251 fn. 2), and Malinowski (1927: 105ff., 1929: 409, 486)), and

- komasi ami popu "eat your shit' is an expression that "lies on the border-line between chaff and insult, and must never be said angrily. Above all, it must never be said in the presence of a chief, and to use it to him as an insult is an unpardonable offence" (Malinowski (1929: 376)).

Mulagugula must know this, of course; nevertheless he pronounces that he will boldly stay in Omarakana and continue to attend the kalibom; moreover he threatens the villagers not to fight with him, the more courageous man implying that the men of Omarakana are cowards. This sequence of the joke (lines 47-53) ends with the narrator's comment that these were Mulagugula's words, indeed.

With line 54 another sequence of the joke begins. There is no more information on what has happened after Mulagugula's speech at Omarakana; we learn now that he and his brother are strolling around the bush after the kalibom; there they meet a pig, a domestic pig (bunukwa) and not a wild one (bwarodina). Mulagugula is hungry and wants to eat it - now as a man of manners - on his wooden plate. But the pig suddenly speaks, puts a spell on Mulagugula, so that he has to do what he told the Omarakana people to do in his earlier curse, and runs away. Mulagugula has to obey this spell and then walks off, too.

This sequence of the joke (lines 54-61) sounds like a fairy tale to the naive non-Trobriand listener or reader: not so for a Trobriand Islander. The people of the Trobriand Islands still strongly believe in the existence and the power of magic (Senft (1985, in press)). By magic, especially by the power of the magic word, they believe they are able to control nature. Knowledge of magic and friendship or political alliance with influential magicians is an important means and factor of power. Omarakana is the center of political power on the islands - therefore a Trobriander hearing this episode of the joke will easily come to the conclusion that the paramount chief did some magic on the pig that meets Mulagugula, and thus made the pig put this spell on Mulagugula as a revenge and a punishment for his horrendous insults. This way of revenging, however, is another proof of the paramount chief's political insight and expertness: realizing that Mulagugula must be somewhat 'crazy', the chief does not even attempt to kill him, something he must do otherwise to keep his face; he reacts according to the obvious difference in status between himself and Mulagugula and - with the help of his magic - just derides him, playing a 'joke' on him which is drastic, indeed, but which redefines the whole context of Mulagugula's "face threatening acts" (Brown and Levinson (1978: 129, 233ff.)) against all the people of Omarakana. 
After this episode, the final sequence of the joke begins (lines 62-69). Mulagugula, together with his mother, who may have looked for her son, comes back to his village. There he sees his brother, handsome Mulakwaku, who has obviously just succeeded in setting up an amorous date with a girl. Mulagugula now leaves the village - and after that, all his life was just work. The joke ends with the information that the beautiful Mulakwaku finally gets married; Mulagugula, however, remains a bachelor - because of his ugliness and of his bad manners (the adjective tomigaga implies both these components).

Given all this information in such an explicit way, information that is culturally immanent in the mutually shared knowledge, values, and conventions of the Triobriand Islanders, we can now fully understand the humor of this story, the humor that makes it a Trobriand joke.

We can list the aspects relative to humor in this joke in the following way:

- Mulagugula is a funny looking man, he is ugly (lines 14, 16-18),

- Mulagugula uses excrement instead of coconut flakes to 'oil' his body; the word 'shit' is topicalized in the story (lines 33-35),

- Mulagugula goes to the politically most important village on the islands; moreover, attending the kalibom implies amorous intentions of the protagonist (lines 24-26, 36),

- the Omarakana villagers react to Mulagugula's odor in the same way they react by scolding an inattentive child returning dirty from the bush-toilet (lines $37,43,46$ ), thus breaking Trobriand etiquette with respect to chiefs,

- Mulagugula publicly accuses all the villagers of being responsible for the terrible smell (lines $40,44,47-49$ ) and escalates his insults,

- Mulagugula produces the two most horrendous insults in Kilivila (line 50),

- Mulagugula derides the villagers of Omarakana as dirty and as cowards (line 52),

- there is a funny discrepancy in Mulagugula being a 'man of manners' (lines 56 and 57), who is able to use rather complex figures of speech (line 40) on the one hand, and behaving like a fool, using the most coarse and blunt language (lines $33-35,40,44,47-52$ ) on the other;

- Mulagugula is bewitched by the spell of a pig into doing the 'impossible' (lines 58-61), and

- Mulagugula's life after this incident is work only; though the story started with his amorous intentions he - in contrast to his brother - must remain a bachelor.

To sum up: The joke evokes humor and laughter in the Trobriand Islander because of the following issues: 
- it topicalizes the foolish and the ugly: "The comic is concerned with the ugly in one of its manifestations" (Freud (1960: 10)), ${ }^{2}$

- it implies components of political satire by the name of the village where the most important part of the action is, thus being tendentious in the Freudian sense (Freud (1960: 90)),

- it topicalizes sex and excrement, breaks taboos and conventions (Freud (1960: 100f., 133f., 137f., 1953: 31-32)), thus revealing the classical components of an obscenity, of a 'dirty' joke (Kiener (1983: 144f., 187, $272 \mathrm{ff}$.)), and

- with Mulagugula's fate it evokes Schadenfreude (Freud (1960: 224)).

With this analysis of the joke, we have answered the question of how to understand the story, and what contextual aspects make it a Trobriand joke. Using the analysis in the following section we will look again at the data presented in section 2 as a whole, and try to answer the question what is going on in this interview.

\section{How to tell a 'dirty' joke in Kilivila}

In section 2 I described the situation that made me elicit the story going with Kilagola's carving. I start the interview reminding the chief of his hinting at the story (lines 1 and 2). Kilagola understands this rather indirect statement as the hedged question intended, namely whether he would like to tell the story. He asks for the carving and agrees to tell the story (line 3 and 4). I hand the carving over to him and comment on Kilagola's intention in the appropriate Kilivila kind of understatement to express my joy (line 5).

Now Kilagola addresses me as an interviewer and his 'audience', as a listener to the story he is going to tell, and starts it with the ritualized formula of opening such a story: mpana kukwanebu (line 6). However, he produces this stereotyped opening together with a - here rather unusual - interjection $(k a)$, and then makes a first pause. He repeats the stereotyped opening of telling a story, pauses again (line 7), and then makes a critical remark on his carving instead of starting with the story, as expected (lines 8-10). After this critical comment, he points at the two carved figures on the stick and introduces them - obviously as the protagonists of the story to be told (lines 11-14). He again interrupts his introduction of the protagonists with another critical comment (line 15), goes on with his description of Mulagugula (lines 16-18), pauses again (line 18), then gives a third critical comment on his work with a kind of justification for the shortcomings in the artefact (lines 19-21), and finishes his introduction of the protagonists with the information that the two carved

2 This is Freud's quotation of Fischer's definition of the comic, of course. 
figures, the male protagonists of the story, are brothers (line 22 and 23). This introductory sequence of the story ends with another pause (line 23).

The sequence just described seems to be quite strange and in need of some analysis. Kilagola is a man who - among other things - is quite famous for his skill as a story-teller and orator. How does it come about that he starts telling a story in such a rather chaotic way? Or: does this introduction look chaotic at first sight only, but is it in fact a stylistic means to achieve some other aims? The four pauses within this sequence indicate that this is a plausible question to ask.

If we look at the interview as a whole, we must keep in mind that the story that goes with the carving is a 'dirty' joke; now, Kilagola is the chief of the village, a person with authority who has agreed to tell this 'dirty' joke to a foreigner, a scientist who is tape-recording his words and who will transcribe and translate what he is going to say; it may be rather inappropriate for a chief to sound like an ordinary wisecracker, a joke-teller, but, if he is mainly criticizing his carved artefact, describing it, and telling the story - the 'dirty' joke - as a mere component of his description, the situation is somewhat different. If we follow the logic of this speculation, we can now analyze this introductory sequence of Kilagola's talking in the following way: While starting to tell the actual story, Kilagola decides, maybe after the first two pauses, to redefine the whole situation of the interview. He is no longer going to tell a 'dirty' joke just for the fun of it, but he is criticizing and describing his work as an artist; doing this also asks for telling the joke, in order to be complete. Thus he kind of "reframes" the situation (Goffman (1974)): the "frame" of telling a joke is redefined and replaced by the "frame" of describing a piece of Trobriand carving to an interested scientist. With the introductory sequence of the story, that is, with the stereotyped opening (lines 6 and 7) and the introduction of the protagonists (lines 11-14, 16-18, 22 and 23) he also "opens the frame" of the critical description of the carving (lines 8$10,15,19-21)$ that will include the 'dirty' joke as one of its components.

The joke proper then starts with line 24 , after the fourth pause in the introductory sequence that may indicate that this first sequence of Kilagola's story telling is finished.

The joke whose contents are analyzed above, formally consists of four sequences: sequence 1 (lines 24-36) describes the protagonists' preparation in order to attend the kalibom in Omarakana. I want to point out here that the irrealis of the verbal expression bisisusi (line 24) is a grammatical means to express the unrealistic, the fictitious character of the story told.

Sequence 2 (lines 37-52) gives the incidents at Omarakana; the escalation of Mulagugula's insults is quite obvious (lines 40, 44, 47, 48, 49, 50, 52).

This sequence of the joke seems to present such a lot of 'strong stuff' for a Trobriander that it asks for a comment by the story-teller. Line 53 of the 
transcription gives this comment: the teller emphasizes that he only reproduces Mulagugula's words - thus somewhow presenting a licence to utter all those taboo-breaking words.

Sequence 3 presents Mulagugula meeting the bewitched pig (lines 54-61).

Finally, sequence 4 (lines 62-69) informs us about the ulterior fate of the story's two protagonists.

If we look at all the four sequences of the joke, it is quite striking that we do not have anything equivalent to a 'punch-line'. This is probably typical for longer jokes in Kilivila that are built in the form of stories. There are very short jokes with punch-lines in Kilivila too, however, in our case the humorous aspects of the story seem to be strong enough, so that there is no need whatsoever for a Trobriander to have a proper punch-line as well.

Kilagola ends his story by referring back to the carving, giving his justification for its shortcomings a second time, hinting at his plan to do the carving once morc, this time in a more refined and more satisfying way (lines 70-74). With these remarks he closes the "frame" he has opened in the introductory sequence.

After this, I continue the interview within the same frame (line 75), and Kilagola goes on with his description of the carving (line 76-85).

With line 86, I intend to finish the interview, thanking the chief for his cooperation: Kilagola responds to my thanks, now explicitly announcing that he will carve another stick to represent this story in a more appropriate way (lines $87-93) .^{3}$

My approving comment (line 94) finishes the interview.

To sum up: Kilagola tells a 'dirty' joke in the following way: after agreeing to tell the story, he intertwines the introductory sequence of the joke with a reframing of the 'joke-telling-situation' into a 'critical-description-of-hisartefact-situation'. He then presents the first two sequences of the joke proper, interrupting his telling the story and thus assuring his licence as a story-teller to reproduce the taboo-breaking ways of speaking, and then finishes the joke proper with sequences 3 and 4 of the story. He finally closes the frame opened in the introductory sequence by criticizing again his artefact that symbolizes the story told.

Table 1 represents this summary of Kilagola's way of telling the joke, referring to lines 3-74 of the transcription given above only.

3 The two carved sticks of ebony are items of Barbara and Gunter Sentt's collection of Trobriand artefacts. 
Table 1

How the joke is told.

\begin{tabular}{|c|c|c|}
\hline Line(s) & Contents & Frames \\
\hline 3 and 4 & Agreeing to tell the joke & \\
\hline 6 and 7 & Opening formula/introductory sequence & Opening of frame: joke-telling \\
\hline $8-10$ & Criticism of carving & $\begin{array}{l}\text { Opening of frame: critical description of } \\
\text { artefact }\end{array}$ \\
\hline $11-14$ & Introduction sequence & Joke-telling \\
\hline 15 & Criticism of carving & Description \\
\hline $16-18$ & Introduction sequence & Joke-telling \\
\hline $19-21$ & Criticism of carving & Description \\
\hline 22 and 23 & Introduction sequence & Joke-telling \\
\hline $24-36$ & Joke: sequence 1 & Joke-telling \\
\hline $37-52$ & Joke: sequence 2 & Joke-telling \\
\hline 53 & Teller's comment (licence) & Comment \\
\hline $54-61$ & Joke: sequence 3 & Joke-telling \\
\hline 62.69 & Joke: sequence 4 & Closing of frame: joke-telling \\
\hline $70-74$ & Criticism of carving & $\begin{array}{l}\text { Closing of frame: critical description of } \\
\text { artefact }\end{array}$ \\
\hline
\end{tabular}

\section{The joke as an example of the Trobriand concept of biga sopa}

The formal and contextual analysis of Kilagola's joke given in the preceding two sections of this paper is another example of the fact that the "difference in the humor of different cultural linguistic groups is not ... one of the means used to achieve the humorous effect (which are similar across cultures) but one of differences in mutual knowledge" ${ }^{4}$ (Dolitsky (1983: 41)). We can only understand the joke and the way it is told in the manner which is adequate to Trobriand standards, if we know something about the joke-teller's assumptions on his and the listener's mutual knowledge. This shared knowledge is presupposed by the teller of the joke - and thus not verbalized; it affects among other things the knowledge of cultural rules and conventions (Davidson (1984), Apel (1984)).

The joke-teller's presupposition with respect to his audience (Freud (1960: 150f.)) of course also affects the latter's shared linguistic knowledge. This linguistic knowledge refers not only to the shared knowledge of the language in which the joke is told, but also to the "pragmatic conventions of [the respective] linguistic community" (Dolitsky (1983: 47)).

4 In this I do not imply that with this knowledge we all must sense the humor of this joke. I must say I do not find it humorous at all; however, the teller assumes that he shares this knowledge with his listeners, and these assumptions are encoded within the joke. I try to make these explicit in analyzing the joke in order to project an idea of why it is so humorous and so funny for a Trobriand Islander. Therefore, I would like to underscore referring to a remark by Wolfgang Klein that knowledge of a certain kind is certainly necessary to perceive something as humorous and funny; however, knowledge is only a necessary, but definitely not a sufficient condition for this. 
I have discussed some of these pragmatic conventions in detail during this analysis of Kilagola's joke. From the pragmatic point of view, however, a joke such as the one presented and analyzed here, is just one example of speech acts that constitute a whole class of a special 'situational-intentional variety' of Kilivila language.

With 'situational-intentional varieties' of Kivlivila I refer to language varieties or 'registers' that are used in a given special situation and that are produced to pursue (a) certain intention(s). Kilivila native speakers differentiate at least seven such varieties (Senft (1984: 76ff.)). The 'situationalintentional variety' which is relevant for us in connection with Kilagola's joke as a speech act is called biga sopa; it can be translated as 'joking language, lying language' or as 'indirect language' and is very characteristic for Trobriand discourse and communication indeed. The biga sopa is based on the fact

"(...) that Kilivila, like any other natural language, is marked by certain features that include 'vagueness' and 'ambiguity'. Both vagueness and ambiguity are used by the speaker as a stylistic means to avoid possible distress, confrontation, or too much and - for a Trobriand Islander at least - too aggressive directness in certain speech situations. If a hearer signals that he may be insulted by a certain speech act, the speaker can always recede from what he has said by labelling it as 'sopa', as something he did not really mean to say. This stylistic means of Kilivila plays an important part in everyday social life on the Trobriand Islands." (Senft (1984: 77))

Jokes are probably the most direct, maybe even the most blunt manifestations of this pragmatic/linguistic concept of Kilivila; however, the function of these speech acts and other, more sophisticated forms of playing on 'vagueness' and 'ambiguity' within the frames of the biga sopa-concept is the same: they all attempt to ensure and to secure a level of 'common ground' within the society; people who laugh together because of a joke - be it aggressive or not - signal that they have 'something in common', that there is a kind of unison - and if someone feels offended because of perceived aggressive directness in a certain speech situation, the believed offender(s) can always release the stress of such a situation by claiming that it was only biga sopa and not an offense or an insult, thus inviting the other to join again the common ground of social harmony: "(...) thus every joke calls for a public of its own and laughing at the same joke is evidence of far-reaching psychical conformity"' (Freud (1960: 151)).

\section{Appendix}

\section{Morpheme-interlinear translation of the 'dirty' joke in Kilivila}

Gunter:

Kilagola yokwa ku-livala pela beya

Kilagola you you-say with/for this 
tokwalu kukwanebu e-sisu

carving story it-exist

Kilagola:

e ku-gisi-la a ke ku-meya

yes you-see-(Emphasis) ah well you-bring

ku-meya ba-yosi ba-livala

you-bring I will - hold I will-tell

Gunter:

e bwena

5 yes good

Kilagola:

so-gu m-pa-na kukwanebu ka

friend-my this-part-this story well

so-gu kukwanebu

this-part-this story

gala ba-vagi te-tolu-la

not I could-make human-three-(Emphasis)

te-tolu-la ba-vagi

human-three-(Emphasis) I should-make

10 ina-si ina-si

mother-their mother-their

e m-to-na yaga-la Mulagugula

yes this-male-this name-his Mulagugula

e m-to-na yaga-la Mulakwaku

and this-male-this name-his Mulakwaku

e m-to-na Mulakwaku to-manabweta

and this-male-this Mulakwaku male-beautiful

taga m-to-na Mulagugula to-migaga

but this-male-this Mulagugula male-ugly

taga beya la-vagi e-bwena

15 but this I-did it-be good

taga kabulu-la beya bi-toki

but nose-his here it will-stand out

mata-la bi-ma beya

eye-his it will-come here

mata-la bi-ma beya

eye-his it will-come here

e ina-si gala ba-vagi pela kai ke-kukupi

and mother-their not I could-make for wood wooden-short

20 a-doki ba-sela ina-si beya

I-think I will-put mother-their here

e m-to-na Mulagugula beya

and this-male-this Mulagugula here

e m-to-na bwada-la

and this-male-this brother-his

Mulakwakula m-to-na

Mulakwakula this-male-this 
bi-sisu-si bi-lo-si

they might have-live-(Plural) they would-go-(Plural)

e-kalibom-si

Omarakana

25 they-do "kalibom"-(Plural) Omarakana

bi-lo-si e-kalibom-si

they would-go-(Plural) they-do "kalibom"-(Plural)

bwada-la bi-lo-si e-kakaya-si

brother-his they would-go-(Plural) they-bathe-(Plural)

bi-kau nuya e-kukwali

he would-fetch coconut he-scrape

e-kukwali bi-vokwa

30 he-scrape he will-finish

i-putuputuma makala pauda

he-oil like powder

e bi-ma i-simwa

yes he will-come he-stay

e m-to-na-ga bi-loki popu

and this-male-this-(Emphasis) he will-go for shit

bi-loki popu bi-gaki la putuma

he will-go for shit he will-make his oil

e-pu e-putuputuma bi-vokwa

35 he-oi.. he-oil hi will-finish

bi-lo-si Omarakana

they will-go-(Plural) Omarakana

bi-ve-si "he maina popu"

they-be on the way-(Plural) hey smell shit

e-lagi e-vavagi-go

he-hear he-do-(Emphasis)

bi-tota e-seki

he will-stand it-show

puva-mi tolivalu yakamesi ugwavaga

40 shit-your (plural) village-people we stranger

e e-ta'ina-ga e-vava'i-si kesosau

yes he-walk arond-(Emphasis) they-hit-(Plural) big drum

bi-ti-ta' ina-ga e-kalibom-si

he will-(Intensity)-walk-(Emphasis) they-do "kalibom"-(Plural)

"he maina popu tauvau"

hey smell shit men

"c-scki pwa-mi tolivalu"

it-show shit-your (Plural) villagers

bi-ta'ina bi-ta'ina bi-kalibom

45 he will-walk around he will-walk around he will-do "kalibom"

bogwa-la "he maina popu"

already-(Emphasis) hey smell shit

"tauvau ku-vagi-si

men you-do-(Plural) 
avela pwa-la

who arse-his

e-seki maina pwa-mi

it-show smell asses-your

kweya-si

mi-kukwava koma-si

ami

50 fuck (Imperative) (Plural) your-wives eat (Imperative) (Plural) your popu a-yobali a-yobili-bali-ga

shit I-stay I-stay-(Intensifier)-(Emphasis)

sulubebeva kwanadu-gu-ma-si"

(sound of tumbling down) rush (Imperative) to fight-me-come-(Plural)

m-to-na Mulakwa... Mulagugula la biga makala

this-male-this Mulakwa... Mulagugugla his speech like

e-ta'ina bi-ma

bi-me-si

he-walk around he will-come they will-come-(Plural)

so-la bwada-la bi-meki mi-na-na

55 companion-his brother-his ++ he will-come this-animal-this

bunukwa bi-kam-kwam o kala kevaga

pig he will-eat-(Intensifier) on his wooden plate

o kala kaboma

on his plate

"yai yai kam-wala koma am popu"

oh no oh no your-only food your shit

e-sakau-la bunukwa

it-run-(Emphasis) pig

i-toli-ga

i-kam bi-kam-kwam

60 he-stand-(Emphasis) he-eat he will-eat-(Intensifier)

bi-vokwa e-kabi

he will-finish he-walk off

bi-ma o si-valu so-la ina-la

he will-come to their-village companion-his mother-his

bwada-la-ga i-vakola vivila

brother-his-(Emphasis) he-hold hands with girl

oluvi i-lola

later he-go away

yam yam la-paisewa

65 day day his-work

makala m-to-na Mulagugula

like this-male-this Mulagugula

e m-to-na-ga Mulakwakula m-to-na

and this-male-this-(Emphasis) Mulakwakula this-male-this

to-manabweta vivila bi-vakola e i-vai

male-beautiful girl he may-hold hands with and he-marry

m-to-na m-to-na-ga gala ve-vai

this-male-this this-male-this-(Emphasis) not he-marry

sena to-migaga e ku-gisi la-teya beya

70 very male-ugly yes you-see I did-carve here 
taga u'ula kai ke-kukupi

but cause wood wooden-small

ba-sela ina-si ina-si

I will-put mother-their mother-their

vivila ba-sela beya

girl I will-put here

Mulagugula Mulakwakula

Mulagugula Mulakwakula

Gunter :

75 e avaka beya

and what this

Kilagola :

beya beya a-doki makala vatunu vatunu a-doki

this this I-think like string string I-think

ba-vagi vatunu ya-bwabava

I will-do string string-plenty

taga a-vagi gala

but I-do not

ke-kekita kai e bogwa mesinau

wooden-small wood and already finished

beya e-vagi i-bubuli kunu-la beya

80 this it-make it-be carved hair-its here

kidamwa la-kabogigisa mwata makala mwata

if its-appearance snake like snake

e beya-ga vatunu makala c-sckwani ya-ta

and this-(Emphasis) string like he-roll string-one

mi-ya-na e-le'i bi-ma beya

this-string-this hc-throw it-come here

e-ma i-kikola beya vatnu mi-ya-na

it-come it-stop here string this-string-this

ya-tala ya-yu mi-ya-si-ta vatunu

85 string-one string-two this-string-(Plural)-this string

Gunter:

bwena agu-toki

good my-thanks

Kilagola:

ba-teya ke-tala ba-vagi migi-la Mulagugula

I will-carve wooden-one I will-do face-his Mulagugula

bi-bwena to-migaga

it will-be good male-ugly

e kabulu-la beya mata-la-ga bi-mwa

and nose-his here eye-his-(Emphasis) it will-come

i-lomwa beya

90 it-stand here

ina-si ba-vagi vivila ina-si

mother-their I will-do girl mother-their 


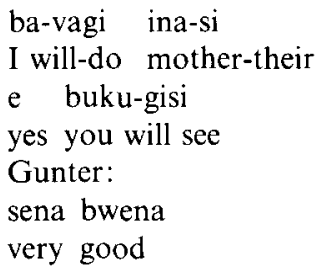

\section{References}

Apel, Karl-Otto, 1984. Comments on Davidson. Synthese 59: 19-26.

Baumann, Richard and Joel Sherzer, eds., 1974. Explorations in the ethnography of speaking. London: Cambridge University Press.

Brown, Penelope and Stephen Levinson, 1978. 'Universals in language usage: politeness phenomena'. In: Goody, ed., 1978. pp. 56-289.

Capell, Allen, 1976. 'General picture of Austronesian languages. New Guinea Area'. In: Wurm, ed., 1976. pp. 5-52.

Davidson, Donald, 1984. Communication and convention. Synthese 59: 3-17.

Dolitsky, Marlene, 1983. Humor and the unsaid. Journal of Pragmatics 7: 39 48.

Freud, Sigmund, 1953. 'Totem and taboo'. In: Complete psychological works of Sigmund Freud, Vol. 13. London: The Hogarth press. pp. 1-161. [1913]

Freud, Sigmund, 1960. 'Jokes and their relation to the unconscious'. Complete psychological works of Sigmund Freud, Vol. 8. London: The Hogarth Press. [1905]

Goffman, Erving, 1974. Frame analysis. An essay on the organization of experience. New York: Harper and Row.

Goody, Esther N., ed., 1978. Questions and politeness. Strategies in social interaction. Cambridge: Cambridge University Press.

Kiener, Franz, 1983. Das Wort als Waffe. Zur Psychologie der verbalen Aggression. Göttingen: Vandenhoeck und Ruprecht.

Lawton, Ralph, 1979. Bulogala Bwaina. Port Moresby and Lae: The Bible Society of Papua New Guinea.

Malinowski, Bronislaw, 1916. Baloma; the spirits of the dead in the Trobriand Islands. Journal of the Royal Anthropological Institute of Great Britain and Ireland 46: 353-430. [Reprinted in: Magic, science and religion and other essays. London: Souvenir Press 1974. pp. 149-254.]

Malinowski, Bronislaw, 1927. Sex and repression in savage society. London: Kegan Paul and Co. [3rd printing 1961, London: Routledge and Kegan Paul.]

Malinowski, Bronislaw, 1929. The sexual life of savages in North Western Melanesia. London: George Routledge and Sons [10th printing 1982, London: Routledge and Kegan Paul.]

Sacks, Harvey, 1974. 'An analysis of the course of a joke's telling in conversation'. In; Baumann and Sherzer, eds., 1974. pp. 337353.

Sacks, Harvey, 1978. 'Some technical considerations of a dirty joke'. In: Jim Schenkein, ed., 1978. Studies in the organization of conversational interaction. New York: Academic Press. pp. 249 269 .

Senft, Gunter, 1984. The core of Kilivila grammar, first draft. Seewiesen: Mimeo.

Senft, Gunter, 1985. Trauer auf Trobriand. Anthropos 80: 471-492.

Senft, Gunter, in press. Weyeis Wettermagie. Zeitschrift für Ethnologie 110.

Weiner, Annette B., 1976. Women of value, men of renown. New perspectives in Trobriand exchange. Austin, TX: University of Texas Press.

Wurm, Stephen A., ed., 1976. Austronesian languages. (New Guinea Area Languages and Language Study, Vol. 2.) Canberra: Australian National University. 